\title{
“NOT EVEN ALL PHYSICIANS KNOW CHINESE MEDICINE!": ANALYSING THE LEGITIMATION STRATEGIES OF CHINESE MEDICINE IN THE ESTONIAN MEDIA*
}

\author{
KATRE KOPPEL \\ PhD student \\ Department of Estonian and Comparative Folklore \\ University of Tartu \\ Ülikooli 16, 51003 Tartu, Estonia \\ e-mail: katre.koppel@ut.ee \\ MARKO UIBU \\ Lecturer \\ Institute of Social Studies \\ University of Tartu \\ Lossi 36, 51003 Tartu, Estonia \\ e-mail: marko.uibu@ut.ee
}

\begin{abstract}
To exemplify the legitimation processes of a pluralistic health field this article focuses on representations of Chinese medicine and its most popular spokesperson, Rene Bürkland, in the Estonian media. From 320 media texts published between 2009 and 2018 we chose 12 for close analysis with the aim of detecting specific discourses, untangling implicit meanings, and demonstrating the complexity of the rhetorical formulations used to legitimate Chinese medicine. We identified five key discourses - discourses of Bürkland's charisma, holistic health, individual autonomy, subtle body, and integrative medicine - underpinning various legitimation strategies which aim to change the position of Chinese medicine from alternative to integrative. Our study reveals that the absence of scientific rhetoric together with key discourses has left Chinese medicine and its spokesperson without the attention of biggest critics of CAM and, therefore, has secured a positive image for Chinese medicine in the public discourse.
\end{abstract}

KEYWORDS: legitimation strategies $\bullet$ media analysis $\bullet$ CAM $\bullet$ integrative medicine $\bullet$ medical experts

* This publication was supported by the University of Tartu ASTRA Project PER ASPERA, financed by the European Regional Development Fund, and by Grants IUT20-38 and PRG670 from the Estonian Research Council. 
Pluralistic health is highly competitive field in which providers and specialists of diverse and numerous treatment methods present themselves as legitimate and trustworthy. Biomedical experts and the defenders of evidence-based scientific medicine have addressed the increasing popularity and professionalisation of CAM (complementary and alternative medicine) as a problem and applied different strategies to diminish its position (Kelner et al. 2004; Caldwell 2017; Lewis 2019). Advocates of CAM, on the other hand, have tried to adapt their strategies accordingly, arguing for integrative medicine, emphasising fulfilment of patient needs and their freedom to choose, and establishing or strengthening relationships with state institutions and policy makers (Hoenders et al. 2011). Although the term CAM is usually used to refer to therapies and teachings that locate outside of biomedical or conventional healthcare (EUROCAM), the particular therapies that are defined either as alternative or complementary are context dependant. Furthermore, legitimation processes for CAM methods and the debates revolving around them, differ in each country as they are strongly influenced by historic, social and cultural contexts.

In Estonia, complex historical background and particular socio-cultural trends have created unique legitimation processes for CAM. From the perspective of the medical system, the boundaries between biomedicine and CAM are remarkably rigid. Estonia, as with other Eastern European post-Soviet countries, has a long-established centralised and exclusive medical system. The training of healthcare professionals is exclusively biomedically orientated, prioritising the role of evidence-based medicine in treatment. Generally, healthcare professionals' knowledge of non-biomedical treatment methods and CAM is limited and simplistic as these practices and approaches are excluded from medical and healthcare curricula as well as the state-financed healthcare system. Both in medical academic literature and public discourse (for example, Tikk 2005; Võsumets 2015), biomedically orientated health professionals usually distinguish two exclusive counterparts - conventional/traditional medicine and alternative medicine. The former is defined as scientific medicine and includes biomedical treatment methods only, and is in accordance with medical ethics. The concept 'alternative medicine' is used for non-biomedical treatment and health methods and is an umbrella term both for complementary and alternative medicines. Methods such as manual therapy, acupuncture, osteopathy, aroma, light and music therapy are called and recognised as complementary medicine because these methods are seen as evidence-based. Alternative medicine includes non-evidence-based methods that are perceived as problematic or simply harmful due to lack of evidence. Such categorisation - conventional and alternative medicine - draws clear-cut boundaries between CAM and biomedicine, emphasising biomedical dominance and marginalising CAM. While evidence-based complementary methods have found certain acceptance in rehabilitation treatment, non-evidence-based healing methods tend to have a critical, if not hostile, reception by medical professionals and health experts (see, for example, Lubi et al. 2016; Uibu 2016b; Uibu and Koppel forthcoming).

At the individual level, on the other hand, non-biomedical and alternative and/or complementary health therapies as well as various health-related teachings are widely 
popular. In Estonia there is a high rate of belief in the grounding principles of alternative medicine, such as energies and extrasensory powers in Estonia. In addition, folk medicine and self-medication are integrated parts of people's everyday lives. Numerous therapies and health-related teachings had and continue to have an important cultural and spiritual position in society since the collapse of the Soviet Union and the opening of Estonia to the international health market. These therapies and teachings provide deeper philosophical and spiritual meanings for health, illness, wellbeing and healing, filling the gap that exists in religious and spiritual domain in contemporary Estonia (Uibu 2016b).

However, high demand for and popularity of various non-biomedical and non-evidence-based therapies have made representatives of state institutions worried about the diminishing authoritative position of biomedicine. Both the Health Board of Estonia as well as the Ministry of Social Affairs have recently undertaken initiatives to promote "science-based healthcare" and increase people's health literacy in order to help them find "evidence-based health information" (Health Board 2019a; 2019b; Nael 2019). Regarding legislative structures, no clear laws have been implemented by the state to regulate and organise the promotion and use of CAM. For years the Estonian Qualifications Authority has issued occupational qualification standards for different "natural and complementary medicines", for example Chinese natural therapy, aromatherapy and homeopathy. Qualification standard certificates, however, do not have any legal power to allow or restrict a therapist who sells products and/or provides services as long as the therapist's activity complies with general consumer regulations set by the Estonian Consumer Protection Board and does not threaten patients'/users' health according to the perception of the Health Board of Estonia (Maarits 2017).

Public discussion on CAM tends to be polarised in Estonia because of the exclusive medical system that has at the same time faced increasing medical plurality/diversity since the 1990s. The high interest of the populace in and demand for CAM is in contrast with policy makers' strong focus on and orientation towards a scientific and evidence-based health system. One of the arenas where such oppositions can be observed is the media, which has increasingly become an integrated part of many institutions, including health, as institutional activities are performed through the media (Hjarvard 2008: 105). Mediatisation (Hjarvard 2008; Lundby 2014; Krotz 2017) evokes changes in the health field as well as influences the reception of health-related products, services and teachings in multiple ways. The media contributes to the public understanding of health and medicine (Briggs and Hallin 2016) as well as providing culturally available narratives, scripts and discourses. These sources of knowledge affect health-related attitudes and decisions at the individual, as well as at the healthcare provider and policy maker, level (Benelli 2003; Seale 2003; Kelly et al. 2010).

Regarding CAM, Laura Weeks and Tina Strudsholm (2008) have demonstrated that the media content is generally positive, and hence, contributes to the professionalisation and legitimation of CAM. Media content normalises ideas about CAM as the providers of these health treatments shape their messages in such a way as to attract supportive media coverage. Journalists and editorials produce, reproduce, and co-produce media content with providers/specialists and circulate selective knowledge of the teachings and techniques they perceive as worthy. While many countries have increasingly incor- 
porated alternative and complementary medicines into medical practice (Coulter 2004; Baer 2008; Hollenberg and Muzzin 2010; Keshet 2013), in Estonia we can see the emergence of a rhetoric of integrative medicine.

Considering the polarised attitudes in the Estonian health field generally, positive media coverage of an alternative and/or complementary health practice can be seen as an important key factor for the commercial success of a CAM method. When applying several rhetorical strategies, the media as a platform enables the introduction and change of meanings related to alternative/complementary treatment, and hence, the transformation of potential patient/user, as well as healthcare professional and policy maker, attitudes towards such treatments and health practices.

In recent years, Rene Bürkland (born in 1974) can be considered one of the most significant practitioners of CAM in Estonia. Bürkland is a practitioner and a well-known spokesperson for Chinese medicine and has received a lot of media attention, contributing to a shift in the meanings related to non-biomedical health practices. In 2009, when Bürkland entered the Estonian health market as founder of a centre for Chinese medicine, he also started to appear consistently in the Estonian media. Since then, but especially since 2014 - the year his first book on Chinese medicine was published (Bürkland 2014) - Bürkland's presence in the media has been constant. Apart from promoting the usage of Chinese medicine among Estonians, Bürkland has argued for the integration of biomedicine and Chinese medicine. Integrative medicine denotes a coordinated and pluralistic effort to address a health problem using diverse health and medical expert systems (Harnett and Morgan-Daniel 2018), reaffirms the importance of the relationship between practitioner and patient, and focuses on the whole person and evidencebased decisions in achieving optimal health and healing (ACIMH). In the Estonian health field, however, integrative medicine is a new and relatively unknown concept. It is not an established approach to health, wellbeing and healing. In Estonia, we can rather talk about the growing visibility of the rhetoric for integrative medicine. Bürkland's methods in introducing Chinese medicine as a potential partner for biomedicine is an outstanding case to study, especially in the Estonian context where the boundaries between biomedicine and CAM are rigid and Chinese medicine is perceived as alternative medicine by the state and biomedical professionals (see also Koppel 2018). Compared to other significant CAM practitioners/specialists, the media coverage of Bürkland is surprisingly positive across the almost ten-year-period of his activity (Koppel and Uibu forthcoming). The polarised attitudes towards CAM that are usually present in public discussion are in Bürkland's case almost non-existent, or very subtle, making him a successful strategist for the legitimation of CAM.

In this article, to exemplify the legitimation processes of CAM we explore the emergence of Bürkland and Chinese medicine in the Estonian media between 2009 and 2018. The main research question of our article is: What discourses and rhetorical constructions are used in media texts to legitimate Chinese medicine and shift its position from alternative to integrative medicine. The analysis of legitimation becomes especially relevant in the context of controversial actions, accusations, doubts, critiques and conflicts (Rojo and van Dijk 1997: 528). Close textual analysis enables us to identify and research different legitimation strategies underpinned by discourses (Fairclough 2003; van Leeuwen 2007; Vaara 2014). We understand legitimations as explanations and jus- 
tifications of social practices in reply to the question why a social practice, or part of it, should take place in the certain way (van Leeuwen 2008: 20).

After preliminary content analysis and thematic coding of 320 media texts published between 2009 and 2018 about Bürkland, we conducted a deep analysis of the discourses and rhetoric of the 12 longest texts. These texts focus on Bürkland as a person and practitioner of Chinese medicine. The analysis of media texts as well as the broader context of Chinese medicine and position of Bürkland presented in the article is supported by ethnographic data. The ethnographic fieldwork conducted in 2016 and 2017 included observations at book presentations, lectures and training events held by Bürkland as well as semi-structured interviews with healthcare professionals who have attended these events (see more Koppel 2018).

In the first section of the article we introduce the position of Chinese medicine in the Estonian context as well as the position of Bürkland. Before continuing with analysis of media texts we describe the methodological background and decisions we have made. The analysis focuses on outlining the main discourses and rhetorical constructions that underpin the legitimation strategies applied in the media texts.

\section{CHINESE MEDICINE IN ESTONIA AND THE POSITION OF BÜRKLAND AS A PRACTITIONER OF CHINESE MEDICINE}

In Estonia, Chinese medicine is practiced by medical doctors, other health professionals, such as nurses and midwives, and by practitioners with no medical background. Practitioners of Chinese medicine usually introduce Chinese medicine within the framework of Taoist philosophy in combination with teachings from New Age spirituality (Sutcliffe and Gilhus 2013) (which are particularly popular in Estonia). From the perspective of treatment methods, Chinese medicine is known to be comprised of a set of different practices such as acupuncture, herbal medicine, massage, qigong, cupping, moxa therapy and food therapy. The background, skills and qualification of practitioners, however, vary. For example, it is possible to distinguish a so-called more spiritual approach to Chinese medicine, which uses elements from Chinese medicine to achieve (spiritual) healing, and a medical approach, which emphasises integration between Chinese medicine and biomedicine. Hence, interpretations and representations of historic Chinese medicine depend heavily on each individual practitioner's education, teachers and sources.

Similarly to other CAM methods no university or healthcare/medical school currently provides teaching programmes in Chinese medicine or its techniques. However, there are occasional single courses on Chinese medicine as part of the study of Chinese culture and language at public universities. Therapists who employ Chinese medicine and/or its particular techniques are trained by a few private schools that focus on continuing education in folk medicine and various healing teachings and methods. In addition, therapists and doctors active within Chinese medicine provide training courses on the methods and philosophy involved. As there are no teaching programmes at the university/college level, Estonian practitioners also seek Chinese medicine related education outside Estonia, for example in China, Russia, Finland, and the US. 
From the perspective of the state and the healthcare system, Chinese medicine is commonly categorised as an alternative medicine. However, of the various Chinese medicine therapies acupuncture has a special status and is perceived as a complementary medicine, as mentioned in the introduction. Due to historical developments, acupuncture as an individual therapeutic technique is recognised as a health service by the state, whereas other practices are left unregulated by law. Being recognised as a health service, and therefore being subordinated to state control, means that acupuncture can only be used as a treatment by licensed medical doctors. This keeps the number of professional acupuncturists very low and the service a niche, in addition to which there are no proper teaching programmes. Although acupuncture is recognised as a health service in a similar way to other Chinese medicine therapies, it is not listed as a statefinanced treatment and the cost of the treatment is not reimbursed to patients. From the perspective of healthcare system the usage of acupuncture and other techniques of Chinese medicine is perceived as a patient's individual decision and responsibility.

However, under the influence of Soviet healthcare traditions, acupuncture was listed as a state-financed treatment until 1997 in Estonia. The fact that acupuncture was removed from the list of financed treatments led to acupuncturists and doctors of Chinese medicine argue to re-establish the bond between biomedicine, state healthcare and Chinese medicine (see more Koppel 2018). One of these doctors was Bürkland, who has become a highly visible and successful practitioner of Chinese medicine in recent years. Bürkland and his activity as a practitioner of Chinese medicine are well known to the general public. He is a popular author whose second book on Chinese medicine occupied the top position on the 2016 bestseller list according to the Estonian Publishers' Association. He is also a lecturer who introduces the principles of Chinese medicine both to lay people and to healthcare professionals.

Bürkland is educated in psychology, biomedicine and Chinese medicine; professionally he could be said to be between different disciplines, health systems and approaches to the human body. After studying medicine for six years and graduating from the University of Tartu as a general practitioner (2006), he went to study at the Beijing University of Chinese Medicine in China. He graduated in 2009 specialising in acupuncture, Chinese massage and herbal medicine. In 2009 after returning to Estonia he founded a centre for Chinese medicine. The centre, soon renamed Alchemy of Health, is currently marketed as a health academy and wellness centre. Regardless of his own interpretations - such as the particular development of illness, perception of Chinese medicine as a way of life that aims to improve an individual's wellness, or the concept of body that is used by many practitioners of New Age spirituality in Estonia (Koppel 2018) Bürkland claims that his approach to Chinese medicine is "classical Chinese medicine" (FM 2016-2017).

In the ten years since it opened Bürkland's centre has become one of the biggest, most renowned and prestigious Chinese medicine centres, providing a wide range of therapies such as acupuncture, tuina massage, herbal medicine, food therapy, cupping, moxa therapy, etc. In addition, the centre trains Chinese medicine therapists, offers training courses on different therapies, and holds regular physical training classes such as qigong, yoga and shindo. The centre has a shop and sells Chinese medicine-related supplements and other health products. 
In addition to being the owner of the wellness centre and providing training courses on various therapies, over the last couple of years Bürkland has been invited to train healthcare professionals in the basics of Chinese medicine at major state hospitals in Tallinn, the capital of Estonia. These training days aim to attract healthcare professionals, including medical doctors, although so far midwives and nurses have shown a greater interest.

\section{DATA AND METHODS}

We collected 320 Estonian news stories related to Bürkland's activity published between 2009 and 2018. The texts vary in length, function and genre. The collection includes short and long articles introducing Chinese medicine, long interviews conducted with Bürkland, Chinese medical health tips as well as announcements related to Bürkland's activity. Some of the texts were written by Bürkland himself, although the majority were written by professional journalists. The texts were published in daily and weekly newspapers, various health and lifestyle magazines, as well as different internet portals that provide daily news as well as medical and healthcare news.

After conducting preliminary content analysis and thematic coding (Kuckartz 2014), we understood that the texts represent Chinese medicine and Bürkland predominantly in a positive manner, suggesting the promotional purposes of the coverage and sympathetic attitudes of the authors. The general topics and patterns of coverage were strikingly similar. This overwhelming positive coverage of CAM has also been noticed previously in different countries such as Germany, the UK and Canada (for example, Ernst and Weihmayr 2000; Weeks et al. 2007). However, because of the tense relationships between biomedicine and CAM in Estonia, such positive coverage of Chinese medicine is surprising and significant. The texts contained several hints about the re-positioning of both Chinese medicine and CAM and revealed some intrinsic tensions related to medical authority and legitimacy.

To explore the mechanisms of legitimation and re-positioning of Chinese medicine more closely we decided to dig deeper into the rhetorical formulations and discourses that surround Chinese medicine. Thus, with the aim of detecting specific discourses, untangling implicit meanings, and demonstrating the complexity of rhetorical formulations used to legitimate Chinese medicine, we chose the 12 longest and most comprehensive texts that focus on Bürkland as a person and practitioner of Chinese medicine for further analysis. We also took into account the diversity of sources of media texts, aiming to cover mainstream news portals, health and lifestyle magazines and publishers of healthcare news (see Table 1). 
Table 1. List of analysed media texts.

\begin{tabular}{|c|c|c|c|}
\hline Title in English & $\begin{array}{l}\text { Date of publishing; } \\
\text { source; author }\end{array}$ & Genre & Reference \\
\hline $\begin{array}{l}\text { Doctor of Chinese Medicine: } \\
\text { "There Is No Herbal Medicine } \\
\text { That Would Do Only Good" }\end{array}$ & $\begin{array}{l}7 \text { July 2011; Internet news } \\
\text { portal maaleht.delfi.ee; Ingrid } \\
\text { Peek }\end{array}$ & Interview & $\mathrm{T} 1$ \\
\hline $\begin{array}{l}\text { Alchemist of the Week Rene } \\
\text { Bürkland: "Balance Is a } \\
\text { Precondition of Health" }\end{array}$ & $\begin{array}{l}13 \text { Nov 2014; Internet news } \\
\text { portal alkeemia.delfi.ee; Ingrid } \\
\text { Peek }\end{array}$ & Interview & $\mathrm{T} 2$ \\
\hline $\begin{array}{l}\text { Rene Bürkland: "A Balance } \\
\text { between Fire and Water Makes } \\
\text { the Body Healthy" }\end{array}$ & $\begin{array}{l}22 \text { Nov 2014; Internet news } \\
\text { portal epl.delfi.ee; Ingrid } \\
\text { Veidenberg }\end{array}$ & Profile & $\mathrm{T} 3$ \\
\hline $\begin{array}{l}\text { Expert in Chinese Medicine } \\
\text { Rene Bürkland: "The Human } \\
\text { Body Can Heal Itself" }\end{array}$ & $\begin{array}{l}\text { Sept 2014; Health and lifestyle } \\
\text { magazine Tervisetark } 9(11) ; \\
\text { Siiri Rebane }\end{array}$ & Profile & $\mathrm{T} 4$ \\
\hline Our Own Oriental Wise Man & $\begin{array}{l}\text { June 2015; Health and lifestyle } \\
\text { magazine Psühholoogia Sinule } \\
\text { 6; Tuuli Elstrok }\end{array}$ & Profile & $\mathrm{T} 5$ \\
\hline $\begin{array}{l}\text { Rene Bürkland: "My Dream Is } \\
\text { to Bring Together Chinese and } \\
\text { Western Medicine" }\end{array}$ & $\begin{array}{l}15 \text { Feb 2016; Medical and } \\
\text { healthcare portal med24.ee; } \\
\text { Madis Filippov }\end{array}$ & Interview & $\mathrm{T} 6$ \\
\hline $\begin{array}{l}\text { Not All Alternative Medicine Is } \\
\text { Equal }\end{array}$ & $\begin{array}{l}\text { March 2016; Health and } \\
\text { lifestyle magazine 60+; Silja } \\
\text { Joon }\end{array}$ & Profile & $\mathrm{T} 7$ \\
\hline Health Stems from China & $\begin{array}{l}28 \text { Sept 2016; Lifestyle } \\
\text { magazine Oma Maitse; Tiiu } \\
\text { Suvi }\end{array}$ & Profile & $\mathrm{T} 8$ \\
\hline $\begin{array}{l}\text { Doctor of Chinese Medicine } \\
\text { Rene Bürkland: "Every Diet Is } \\
\text { Healthy If You Eat the Right } \\
\text { Amount at the Right Time" }\end{array}$ & $\begin{array}{l}8 \text { Oct 2016; Internet news } \\
\text { portal elutark.delfi.ee; Inge } \\
\text { Pitsner }\end{array}$ & Interview & T9 \\
\hline $\begin{array}{l}\text { Rene Bürkland: "Why Do } \\
\text { Estonians Have so Much Heart } \\
\text { Disease? Because There Is Too } \\
\text { Little Joy in their Hearts" }\end{array}$ & $\begin{array}{l}15 \text { Oct 2016; Tabloid Õhtuleht; } \\
\text { Sirje Rattus }\end{array}$ & Interview & $\mathrm{T} 10$ \\
\hline $\begin{array}{l}\text { Radar: Two-year Waiting Lists, } \\
\text { Bestselling Books: What Is the } \\
\text { Phenomenon of the Healer Rene } \\
\text { Bürkland? }\end{array}$ & $\begin{array}{l}25 \text { Oct 2016; Internet news } \\
\text { portal publik.delfi.ee; Portal's } \\
\text { editor }\end{array}$ & Profile & $\mathrm{T} 11$ \\
\hline $\begin{array}{l}\text { Chinese Medicine Helps You } \\
\text { back on Track }\end{array}$ & $\begin{array}{l}\text { Feb 2018; Health and lifestyle } \\
\text { magazine Kodutohter; Elise } \\
\text { Järvik }\end{array}$ & Profile & $\mathrm{T} 12$ \\
\hline
\end{tabular}


Our analysis of these 12 texts is two-fold. Firstly, we applied qualitative content analysis to identify the main topics and discourses. These key discourses have a central role in the legitimation of Chinese medicine. As discourses are always related to previous discourses, and those produced simultaneously and subsequently (Titscher et al. 2000: 148), we provide context for every identified discourse, from the perspective of intertextuality and sociocultural knowledge. Secondly, we look more closely into particular rhetorical formulations and provide examples from the analysed media texts.

The analysis is also supported by the almost two-year ethnographic fieldwork conducted in 2016 and 2017. The fieldwork included observations at public events such as book presentations, radio broadcasts, training events, and lectures held by Bürkland. These events were targeted either at healthcare professionals (including prospective healthcare professionals) or a wider audience, although in both settings the aim was to introduce and popularise Chinese medicine. In addition, the fieldwork period included semi-structured interviews with healthcare professionals who attended Bürkland's lectures and training days as well as the organiser of a training day at a major hospital in Tallinn (see more Koppel 2018).

Although the main focus of our article is on media texts, attending these events and talking to health professionals helped us understand and compare the rhetorical choices and constructions that are presented in media texts, and which Bürkland makes when speaking to different audiences. Moreover, ethnographic data have helped us better contextualise the media texts and discourses that we identified in the texts.

BECOMING AND BEING A HEALER:

THE CONSTRUCTION OF BÜRKLAND'S CHARISMA

The concept of charisma has been used to characterise the success and power of religious, political, and business leaders (see, for example, den Hartog and Verburg 1997; Bligh and Robinson 2010; Takala et al. 2013). Personality traits characteristic to particular leaders have been discussed by many authors (for example House et al. 1991; Bryman 1992; Crant and Bateman 2000). According to Max Weber (1978 [1947]) the core of charisma is a quality of individual personality that followers consider extraordinary. In his essay George P. Boss (1976) elaborates on the attributes of the rhetorical aspects of charisma, pointing out that, among other things, a charismatic leader usually has an inspiring and masterfully delivered message, and a mission that requires urgent resolution.

Proponents of CAM too have often been treated as leaders with extraordinary qualities by their followers (Cant and Sharma 1999: 55). In media texts, the constant construction of Bürkland's charisma was executed through elements such as exceptionality, personal mission, the presence of followers and a special personality trait - a proactive personality, as exemplified by the different initiatives that he has undertaken. From the childhood Bürkland was perceived as an independent learner, which later led to him finding ways to go to China and study Chinese medicine. Many earlier articles introduced him as the founder of the Centre for Chinese Medicine, and more recently as a writer and author of Chinese medical books. 
Regarding Bürkland's exceptionality and his personal mission, his life story was represented as a coherent narrative of events that all served the purpose of becoming and/or being a healer, both as a physician and as a practitioner of Chinese medicine. Bürkland's personal mission or predetermination to become a healer was used to signify his exceptionality. For instance, in contrast to other children who liked oriental martial arts, it is claimed that Bürkland was interested in 'health arts' (T11, see also T2). Another frequently used element that emphasises his extraordinary life story was an advertisement for Vietnamese Balm, a common alternative medicine in the Soviet Union, which Bürkland found as a little boy in his home. In the texts (T3-T6) the advertisement is transformed into a sign of external guidance that foretold Bürkland's future as a healer.

In 1981 seven-year-old Rene Bürkland found a pocket calendar with an advertisement for Vietnamese Balm depicting the body and showing where to apply the ointment. The drawing was apparently so exciting for the boy that he redrew it himself. In 1994 Bürkland, who studied psychology in Tallinn, attended a course on Chinese medicine in Estonia. This is how the seed was planted that led to Rene Bürkland being recognised today, and a popular doctor of Chinese medicine. (T5)

The experiences of and references to Bürkland's patients (for example T3, T4, T11) made visible the existence of followers. Media photos of 'health fans', as sometimes the readers and followers of Bürkland were called, illustrated how the famous as well as the anonymous gathered at Bürkland's public events, marking, thus, his community and recognising and validating him as a charismatic leader.

The construction of Bürkland's charisma provided the basis for developing his personal and expert authority. Throughout the media texts Bürkland's name alone, and frequently the name together with extensions such as doctor, physician, expert or healer, functioned as legitimisers for a broad array of reasons to use Chinese medicine. On the other hand, the discourse on Bürkland's charisma made it possible for conformity legitimation, as linguist Theo van Leeuwen (2008: 109) calls it, to appear and implicitly deliver the message "everybody else is doing it, and so should you". The claims that patients wait for months (T3), and, in more recent texts, for years (T5, T6, T8, T11) to get to Bürkland's appointment emphasised the deficit of his time and expertise, and, therefore, legitimizing Chinese medicine as highly valuable.

In the following extract we can identify the presence of conformity legitimation invoked in the journalist's remark that Bürkland's broadcast caused the 'boom' and the 'shortage' of organic tangerine peel in Estonia. At that time, organic tangerine peel was a niche product unknown to eco shops and only sold at Bürkland's Centre for Chinese medicine in Tallinn. Hence, the increased demand on the market could relatively easily cause a 'boom' and 'shortage' as there was only one provider. This type of media coverage, however, exemplified Bürkland's affect and popularity and overnight made tangerine peel his trademark.

Journalist: Among many good and useful plants we mentioned one which brings to mind a tragicomic situation that happened few weeks ago. After you spoke about the benefits of tangerine peel in a TV show there was a boom in consumption of tangerine peel, and a shortage has emerged in Estonia. (T9) 
When responding to the journalist's question, Bürkland relied on his personal and expert authority:

This was a great lesson for me, that if you give an example then you should not leave an impression that it is miraculous medicine. Tangerine peel IS NOT a miraculous medicine, just as ganoderma or other plants are not. I emphasise: It is not that case that if Bürkland says a plant is good then everybody should buy and use it! On the contrary - a human being must use two tools to make a choice. These tools are the mind and cognition-intuition. Regarding the mind, I think that this new book [Bürkland 2016] has quite a lot of information that a person can apply: "Ahh, these plants take dampness out and I pick these plants which match with my symptoms." (T9)

Similarly to many spiritual and New Age teachers and gurus (see, for example, Hammer 2001), Bürkland claims that his words should not be taken literally, but everybody should analyse and experience what is right for them as individuals. By seemingly diminishing his position as a teacher or guru, he skilfully strengthens his personal authority when encouraging people to experiment with different non-traditional and alternative medicines as his suggestions imply that these individual experiments should be carried out in the framework of Chinese medicine.

The extracts above also demonstrate how media coverage produces, reproduces and circulates medical knowledge (Briggs and Hallin 2016) - in this case, CAM-related medical knowledge. Bürkland emphasises how tangerine peel is not a miraculous medicine giving, the impression that it is a 'normal', a 'real' medicine, and, hence, he enables readers to draw parallels with biomedicine. The whole situation is described with expressions like 'tragicomic' and 'a good lesson', which gives the reverse effect of an apparently funny incident. Readers are reminded that tangerine peel, like medicine generally, should be consumed carefully according to the guidelines which, in this case, are provided in a book written by Bürkland. Moreover, the media coverage affirmed the image of tangerine peel as the most popular and widely used 'medicine' among Estonians.

Bürkland's authority, which functioned as legitimiser for various statements, was made visible and emphasised in two ways throughout the texts. Firstly, journalists often chose the genre of interview (as with the extracts above) to introduce Bürkland and the principles of Chinese medicine. Secondly, articles written other than in the interview genre used a lot of direct speech from Bürkland. These journalistic choices could be part of stylistic techniques or simply contemporary journalistic trends in writing; however, the interview format and statements represented as direct speech by Bürkland have a remarkable effect. Such framing constantly reminds the reader whose voice is speaking, and, hence, validates more strongly the credibility of the statements.

\section{CHINESE MEDICINE AS 'THE WAY TO HEALTH': THE HOLISTIC HEALTH APPROACH}

What is health and what is considered to be healthy are always ideological questions. In health studies two discourses of health have often been identified (for example Lup- 
ton 1995; Anderson et al. 1999; Nordenfelt 2007): the traditional, moralistic view that sees health as the absence of medical conditions (Jensen 1997: 420); and the so-called holistic approach which perceives health "as a resource for the fulfilment of desires and needs in everyday life" (Korp 2010: 802). Holistic health discourse focuses on "positive health' - instead of risk avoidance it emphasises what people should do to increase their wellbeing and quality of life. The holistic health approach is characteristic to CAM as well as to health promotion in public health.

In the media texts analysed the discourse of holistic health underpinned the perception of Chinese medicine as "The Way' to health" (for example T9, T12), which should be undertaken by an individual who wanted to become, be and stay healthy. Health itself was constructed as a 'super-value' encompassing all that is good in life, as Robert Crawford (1980) has put it. Finding harmony and balance between physical activities, the mind and the spirit, as well as between work and leisure, were the core elements of taking care of one's health throughout the texts. To achieve harmony and balance, the discourse of holistic health was blended with, and underpinned by, the discourse of naturalness. The texts emphasised that people were "part of nature" (T9), these two "form[ed] a whole" (T2) and, thus, "according to Chinese medicine to stay healthy a human being must live in accordance with the laws and rhythms of nature" (T12). Based on such arguments the media articles were full of guidelines on how individual bodies should be regulated for the purpose of health maintenance. Moreover, sometimes a third, national, discourse was intertwined with the discourses of holistic health and naturalness, for example, "In Dr Bürkland's opinion, Estonians have always been health-conscious and lived close to nature, regardless of the political regime" (T4) (similar motifs also appear in T5, T8).

The discourse of holistic health clearly provided a basis for rationalisation strategies emphasising the usefulness of Chinese medicine and through this legitimating its use. The texts claim that following the principles of Chinese medicine would "change our life path into pleasure" (T1) and bring "energy" that "allows us to do whatever we want" (T1). The users of Chinese medicine were stated to "have good concentration abilities, sharp thinking and good memory" (T2). No rationalisation, however, can function without moral evaluation (van Leeuwen 2008: 113). These positive effects and beneficial features of Chinese medicine imply underlying moral values such as intellectual productivity, physical vitality, juvenility and personal happiness, which can be associated with the values of the middle class. This gives us the idea that working-age middle class white-collar people would probably be perceived as potential readers of these media texts.

The following example of rationalisation is particularly interesting because of the specific rhetorical construction. The sentence, from an interview with Bürkland, is written in the context of cardiovascular disease and implies that Chinese medicine helps prevent cardiovascular disease: "If you get your diet, work and emotions balanced, there is no reason why your genetic peculiarity should be revealed" (T10). The statement suggests that Chinese medicine is highly effective regardless of genetic predisposition. The effects of CAM and its evaluations, however, are much disputed within medical community and by proponents of CAM (for example, Denny 1999; Keshet 2009; Schmidt 2009; Ernst 2011; Moral-Munoz et al. 2014). In the Estonian context the efficacy of CAM, especially of alternative medicines, is an extremely polarising topic that gives 
rise to public dispute on what is science and pseudo-science, which healing methods can be considered evidence-based and which not, and where the boundary is between rationality and irrationality (see also Koppel and Uibu forthcoming). To claim explicitly that Chinese medicine is effective in preventing cardiovascular disease would be debatable in the light of clinical trials and the argument could be scientifically contested. The rhetorical construction used in the media article helps avoid direct confrontation and uncomfortable debate on efficacy.

\section{BÜRKLAND'S PATIENTS SEEK HELP: EMBRACING INDIVIDUAL AUTONOMY}

The discourse of holistic health is closely related to the discourse of individual autonomy. The essence of individual autonomy relies on the idea that an individual has the freedom and right to make choices about his or her personal life. This same idea also covers health-related concerns. In a neoliberal context individuals are increasingly encouraged to take the role of consumer and to seek actively healthcare products and services (Cant and Sharma 1999; Fries 2009; Nettleton 2013). The context of medical plurality/diversity allows people to select and make decisions about the medical options that suit them best as well as combine and integrate different treatment methods (Wiese et al. 2010). However, as much as an individual has the freedom to make choices about health, the underlying assumption within the discourse of individual autonomy is that one also needs to take responsibility for one's health (for example Hughes 2004; Miskelly 2006).

In the media texts the freedom to make choices about one's health was depicted as a standard and ordinary part of daily life. The texts constantly encouraged the readers to implement the principles of self-care, such as following health and diet tips from Chinese medicine and engage in particular body-mind exercises. In addition, the texts introduced principles of self-diagnosis by explaining how to diagnose yourself based on self-surveillance and observations of one's body. Bürkland's patients were constructed as independent seekers who wanted to participate in the maintenance of their health and in healing process (for example T4, T11). It was the patients' proactive character that led them to look for different medical options and to find their way to Chinese medicine and Bürkland.

In this discourse, moral evaluations were most often used to legitimise the usage of Chinese medicine and the services of Bürkland's centre, evoking the notion of personal responsibility. Usually disease/illness was perceived as a result of an "unsuitable diet" (T8), "negative emotions" (T5) or incorrect lifestyle choices ("consequently, a person has done something wrong" [T12]). Chinese medicine, in contrast, was represented as the right choice, one that can help the organism/patient get "back on track" (T12, T5). Therefore, Chinese medicine is constructed not as an unnatural intervention but as something that helps people return the body to its natural path, highlighting the individual's forthcoming responsibility - "the work a person has to do with himself" (T3).

In the following extract the journalist quotes Bürkland describing his patients as more conscious and more motivated, implying that they have taken individual responsibility for their health. Here he seamlessly connects higher motivation and healthawareness with the use of Chinese medicine and attendance at his wellness centre. 
"Increasingly people who are more conscious and motivated reach out to our clinic. They want to do something to become healthy. They do not come to see the doctor, do not put their health in the doctor's hands by saying 'fix it', but they want to know what to do. They ask how to eat, how to change their lifestyle," says Rene Bürkland. (T7)

The decision to use Chinese medicine, however, is not only presented as being about achieving personal well-being, it is also represented as the responsible citizen's duty to the state and state healthcare system. This link between Chinese medicine and state healthcare is achieved through particular wording, such as using the word doctor/ physician instead of practitioner of Chinese medicine, and the word clinic instead of the Centre for Chinese Medicine or the centre's name, Alchemy of Health. The wording implicitly emphasises how Bürkland's patients really want to 'become healthy', in contrast to passive consumers of state healthcare. The underlying moral evaluation is an implication of rationality - the more we have patients who are autonomous in their healthcare decisions, the healthier people are and the less pressure falls on state healthcare.

\section{SELF-HEALING BODY: THE DISCOURSE OF THE SUBTLE BODY}

The perception of the body prompts fundamental difference between CAM and biomedicine (Coulter 2004) as they draw on entirely different discourses. In CAM the body is thought to be comprised of a "vital force" that makes it possible for the body to heal itself (Barcan 2011). This perception is based on the so-called subtle body model, i.e. in addition to the physical body, there is an invisible body (Johnston and Barcan 2006; Johnston 2010). The life force, or energetic "substance", is understood to interpenetrate both the physical body and the metaphysical agency, i.e. the subtle body (Johnston 2010: 70). It is believed that the organs in the physical body have energetic subtle matter counterparts and that the body has internal pathways of subtle energy. In the media texts, notions like energy, qi, shen, or 'kidney energy' as well as descriptions of how different body parts and organs are interrelated with each other, were clear references to subtle body discourse.

The discourse of the subtle body provided the basis for rationalisation strategies, making it possible to argue for the usefulness of Chinese medicine compared to biomedicine. There were differences between the texts depending on the targeted or imagined readers. For example, a text published in the medical portal med24.ee claimed that Chinese medicine was useful in diagnosis. In the example below, there are no explicit references to $q i$ or other common terms of Chinese medicine that mark the subtle body discourse, rather, Bürkland uses the phrase "something is wrong", masking the otherwise incomprehensible concept of the subtle body for Western medicine. This intangible 'wrongness' could be apprehended by diagnostics used in Chinese medicine: "On the other hand, the patient is not sick in terms of conventional medicine, but something is wrong. This is the period during which the diagnostic techniques of Chinese medicine can diagnose where the problem is". (T6) 
Other texts targeting a wider audience contained claims that Chinese medicine was useful both for diagnosis and treatment: "Chinese medicine can diagnose and treat problems on the level of energy. Western medicine does not start treatment until the disease is physically diagnosed" (T10); "Our bodies give us signs that something is wrong before the disease emerges. If we can read the signs, we can treat the disease before it emerges." (T7)

Subtle body discourse is manifested either explicitly (the former extract) or implicitly (the latter extract). All similar claims by Bürkland make some references to time. In the last two examples, adverbs relating to time "not until" and "before" clearly position Chinese medicine ahead of biomedicine on an imaginary timeline. These adverbs emphasise how Chinese medicine has the advantage of being quicker in detecting disease and providing care.

\section{CHINESE MEDICINE: NEITHER ALTERNATIVE NOR COMPLEMENTARY MEDICINE, BUT INTEGRATIVE}

Since the 1990s the discourse of integrative medicine has slowly evolved in the US and other Anglophone countries. Integrative medicine aims to merge the best of alternative and complementary medicine with biomedicine, using diverse health and medical expert systems and drawing on evidence-based scientific thinking. The emphasis is on preventative care, maintenance of health and the patient's wellness and wellbeing as a whole person ( $\mathrm{Ng}$ et al. 2016). The discourse of integrative medicine has emerged from and is combined with existing discourses, some of which, such as the discourses of holistic health, individual autonomy, and the subtle body, we have discussed above.

In addition, however, we identified specific elements of integrative medico-scientific discourse. For example, the media texts stated that Bürkland sometimes recommended using antibiotics (T3) or painkillers (T12) or that patients visiting Bürkland could bring with them their medical data, which would then be analysed at the appointment (T7). The text published in the med24.ee portal particularly depicted Bürkland as a representative of scientific thinking who asks questions, has doubts, and studies Chinese medicine from the perspective of the principles of evidence-based medicine.

The discourse of integrative medicine mainly provided a basis for conformity legitimation, moral evaluation and rationalisation. Conformity legitimation was much used in the med24.ee text, for instance, "now physicians' interests in Chinese medicine has grown too" and "we collaborate widely with sports medicine doctors, orthopaedists, neurologists and endocrinologists" (T6). Emphasising physicians' growing interest and excluding nurses and midwives is a strategic choice aimed at legitimation. As ethnographic fieldwork has demonstrated, nurses and midwives tend to be more active participants than physicians in Bürkland's training days, for example (Koppel 2018). Conformity legitimation was observed to emerge together with rationalisation. In the example below, patients' growing demand for Chinese medicine is used as an argument to justify more practitioners of Chinese medicine. Long waiting lists, which would be interpreted as signs of dysfunction within the state healthcare system, are presented as signs of high demand. Moreover, the options for biomedical physicians to offer services of Chinese medicine are naturalised and presented as potential future development. 
RB: The waiting list for an appointment with me is 2.5 years. We stopped adding people half a year ago, but the waiting list for the other doctors at our centre is around 3-4 months. This is worse than in the state system. We need more doctors to be engaged in Chinese medicine. I even do not think that we should have more centres for Chinese medicine but rather medical doctors could use the possibilities of Chinese medicine. (T6)

The second commonly applied legitimation was moral evaluation (for example, "Medical doctors are becoming more and more open to and aware of the methods of Chinese medicine" [T5]). Moral evaluations can also be expressed through analogies, referring to other activities that are associated with positive values (van Leeuwen 2008: 111-112). The following example gives the impression that in principle the difference between the work of a Chinese medical practitioner and a family physician (i.e. general practitioner) are not significant as Chinese medical practitioner is also able to find solutions to a wide array of health problems: "Rene Bürkland explains that he works like a family physician - his patient could be a six-month-old or a 95-year-old, and the complaints could be very different" (T3).

In the same article, moral evaluations legitimised Chinese medicine as a natural part of the normal healthcare service and medical education. The combination of Chinese medicine and biomedicine was presented as "the most patient-friendly treatment method", which "unfortunately" can be practiced by "few" family physicians "only", as "even" the most respected university in the country has no courses on alternative medicine in their medical curriculum (T3, see also T4, T6). The combination of Chinese medicine and biomedicine was rationalised by explaining the benefits of an inclusive approach for the various stakeholders. The interview published in the med24.ee portal emphasised the benefits that the state and physicians could gain: "The patient, as well as the state, wins from this as it is much cheaper to prevent, than to treat, disease. In addition to which physicians' workloads would decrease." (T6)

Articles published in lifestyle magazines, on the other hand, stressed the advantages that patients, citizens and people as members of society could receive: "“If using Western and Chinese medicine together, everybody wins from this: the patient gets healthy earlier and gets less sick, the medical system has less burden and people are happier and healthier,' he adds" (T5).

Interestingly, the idea of healthy and happy people is compatible with the vision of the Estonian Medical Students' Association, which states that their aim is that the healthiest and happiest people on Earth would live in Estonia (EAYS). Hence, such arguments have the potential to speak to a younger generation of doctors since the goals of both practitioners of Chinese medicine and prospective medical professionals are represented as overlapping. Moreover, in spring 2017 medical students at the University of Tartu invited Bürkland to give a lecture on Chinese medicine and introduce its value for biomedicine and healthcare.

\section{MISSING DISCOURSE: SCIENTISM}

What is significant and intriguing about the media texts, though, is the absence of an important and widely applied component of the legitimation of CAM and alternative 
health teachings, science and scientism, which are often used by proponents and practitioners of CAM (see, for example, Hammer 2001; Ng et al. 2016). By scientism we mean references to scientific research evaluating the efficacy and safety of CAM therapies. Chinese medicine, especially acupuncture and herbal medicine, are clinically much studied in different parts of the world (for example, Leung et al. 2006; Wiese and Oster 2010; Moral-Munoz et al. 2014). Easily accessible international evidence-based research could potentially have been used to build up legitimation tactics throughout the media texts. Instead, this was only done once in the interview published in the medical portal med24.ee.

RB: Israeli oncologist Dr Yair Maimon, who is also a Chinese medicine doctor, gave a very interesting talk there [at a conference]. Based on the results of his research on breast cancer patients who had received chemotherapy, he had developed a herbal preparation. [...] I was very impressed that he had combined Chinese and Western medicine, that is, he had researched this herbal mixture purely according to the criteria of Western science. [...] The results, which he published in Western medical journals (should anyone have interest in these publications, you may contact me), showed that this preparation greatly reduced the side effects of chemotherapy. (T6)

On the other hand, discourse of scientism was clearly present and provided a basis for legitimation in ethnographic data documented in 2016 and 2017. However, it is important to emphasise that we could identify the discourse only in the data documented at events targeted to the medical/healthcare community. For example, Bürkland presented references to scientific research and discussion on evidence, efficacy and safety in order to explain the value of Chinese medicine at a training day for healthcare professionals as well as during his introductory lecture to Chinese medicine at the University of Tartu. Observations conducted at other events that targeted a wider and non-medical audience showed that Bürkland normally did not use the discourse of scientism to legitimise Chinese medicine therefore demonstrating a selective and strategic choice of discourses and connections.

\section{DISCUSSION AND CONCLUDING REMARKS}

This article has explored the discursive and rhetorical constructions of the legitimation of Chinese medicine, which is usually perceived as an alternative to biomedicine by the state healthcare system in Estonia. Our analysis of media texts demonstrates in detail how providers of Chinese medicine have striven to frame Chinese medicine as a valuable and legitimate option for potential clients/patients, and an equal and useful partner for biomedicine and state healthcare. Rather than the critical approach that can be observed to some other Estonian medical doctors who promote CAM (Koppel and Uibu forthcoming), journalists and editors have surprisingly enabled Rene Bürkland to present discourses that support his practice.

We identified five key discourses underpinning various legitimation strategies that aim to change the position of Chinese medicine from alternative to integrative medicine: of Bürkland's charisma, of holistic health, of individual autonomy, of the subtle body, and of integrative medicine. When looking at the key discourses and rhetorical con- 
structions, it becomes apparent that media texts strengthen the image of Chinese medicine as a method that helps, on the individual level, to prevent disease and maintain health, and supports the medical and healthcare system in curative and preventative treatment. The constant flow of media texts about Bürkland and Chinese medicine have created a consistent platform of information for those who are interested in Chinese medicine. The key discourses have provided the basis for the production and reproduction of positive image of Bürkland and Chinese medicine. In the health market, where people choose their service provider, public image is undoubtedly very important.

The Estonian healthcare system is currently exclusively biomedical and evidenceorientated. Being a healthcare professional practicing CAM can involve certain risks such as conflict with medical and healthcare institutions or even losing one's doctor's license (for example, Koppel and Uibu forthcoming). As the medical and healthcare system is rigid, it is also difficult to change attitudes to CAM at the state policy level. For example, the Estonian Health Insurance Fund has stated that acupuncture could be re-listed as a state financed treatment only if medical doctors find it necessary (Ilves 2017). Hence, it is crucial to create public demand for Chinese medicine among patients and, in addition, achieve amicable attitudes among healthcare professionals. It seems that the media texts have contributed to the construction of the positive image of Chinese medicine among some medical specialists, which might potentially help to change the position of Chinese medicine in the healthcare system. For example, this positive image made it possible for Bürkland to give an interview to the medical portal med24. ee, which is otherwise exclusively focused on evidence-based medicine. Furthermore, this positive image encouraged the organisers of the training day at the state hospital to invite Bürkland to speak. "This knowledge was all the time in society. He was quite strongly 'in the frame' and in that sense it wasn't difficult to make the first step," as one of the organisers explained in the ethnographic interview (FM 2017). Therefore, we can see that there is a certain type of acceptance of Chinese medicine by the medical community, and that the first endeavours towards integrative medicine are already taking place.

A crucial aspect that has helped to legitimate and create a positive image of Chinese medicine is the lack of scientism in the media texts. Bürkland's avoidance of scientific rhetoric is a significant choice that reveals certain features characteristic to the Estonian context particularly. Science and non-science (or 'esoterica' as it is often called in Estonian) as well as evidence-based medicine and alternative medicine are commonly constructed as contradictory oppositions provoking heated debate in the public discourse. Those debates that try to engender dialogue frequently fail. The roots of this opposition can be most explicitly seen in the Soviet heritage and its triumph of materialistic ideology when officially science and religion, as well as 'science-based biomedicine' and 'belief-based alternative medicines', were perceived as incompatible domains. Since the collapse of the Soviet Union, Estonia has witnessed remarkable changes in the health landscape. The opening of the health market to international teachings and therapies in the 1990s brought many new forms of diversity, including various alternative and complementary health treatments. The heated debate surrounding biomedicine and alternative medicine reflect the separation and philosophical dissension that still exist between the domains of science and religion, and biomedicine and CAM (see also Uibu 2016a). The media articles we analysed illustrated that Bürkland takes a distant and 
cautious position on such disputes. Moreover, his key discourses and legitimation strategies were picked in such a way as to avoid direct opposition and conflict between Chinese medicine and biomedicine. The absence of the discourse of scientism functions as an important strategy that legitimises Chinese medicine, creating a safe, non-conflict zone, for it. This approach has left Chinese medicine and Bürkland without the attention of the biggest critics of CAM and proponents of evidence-based scientific medicine, enabling his voice to be heard more often, and in a more positive way, in media coverage across various platforms and publications.

\section{SOURCES}

FM 2016-2017 = Katre Koppel's fieldwork materials from 2016-2017. The materials are kept in the author's personal collection.

List of media texts:

T1 = Peek, Ingrid. 2011. Hiina meditsiini tohter: Ei ole sellist ravimtaime, mis ainult head teeks. - Maaleht. https://maaleht.delfi.ee/elu/hiina-meditsiini-tohter-ei-ole-sellist-ravimtaime-misainult-head-teeks?id=48994669 (accessed February 23, 2020).

T2 = Peek, Ingrid. 2014. Nädala alkeemik Rene Bürkland: tervise eelduseks on tasakaal. - Alkeemia. ee. https://alkeemia.delfi.ee/hallokosmos/uusmaailm/nadala-alkeemik-rene-burkland-terviseeelduseks-on-tasakaal?id=70129023 (accessed February 23, 2020).

T3 = Veidenberg, Ingrid. 2014. Rene Bürkland: tule ja vee tasakaal kehas annab tervise! Eesti Päevaleht. https://epl.delfi.ee/lp/rene-burkland-tule-ja-vee-tasakaal-kehas-annabtervise?id=70196807 (accessed February 23, 2020).

T4 = Rebane, Siiri. 2014. Hiina meditsiini ekspert Rene Bürkland: "Inimese keha suudab ennast ise tervendada." - Tervisetark 9 (11): 16-20.

T5 = Elstrok, Tuuli. 2015. Meie oma Idamaa tark. - Psühholoogia Sinule 6: 12-17.

T6 = Filippov, Madis. 2016. Rene Bürkland: minu unistus on ühendada Hiina ja Lääne meditsiin. - Med24. https://www.med24.ee/uudised/newwinprint/aid37494 (accessed September $25,2016)$.

T7 = Joon, Silja. 2016. Kogu alternatiivravi ei tasu ühte patta panna. - Postimees 60+. https://60pluss. postimees.ee/3617099/kogu-alternatiivravi-ei-tasu-uhte-patta-panna (accessed February 23, 2020).

T8 = Suvi, Tiiu. 2016. Tervis tõuseb Hiinast. - Oma Maitse. http://digi.omamaitse.ee/artiklid/tervistousebhiinast?id=75728909 (accessed October 10, 2016).

T9 = Pitsner, Inge. 2016. Hiina meditsiini arst Rene Bürkland: Igasugune toitumine on tervislik, kui sööd seda õigel ajal õiges koguses. - Elutark. http://elutark.delfi.ee/tervis/hiinameditsiiniarstreneburklandigasugunetoitumineontervislikkuisoodsedaoigelajaloigeskoguses?id=75844739 (accessed December 13, 2016).

T10 = Rattus, Sirje. 2016. Rene Bürkland: miks on eestlastel nii palju südamehaigusi? Sest südames on liiga vähe rõõmu. - Õhtuleht, October 15, 2016: 20-21.

T11 = Publik.ee. 2016. Radar: Kaheaastane järjekord, enimmüüdud raamatud: milles seisneb ravija Rene Bürklandi fenomen? - Publik.ee. http://publik.delfi.ee/news/inimesed/radarkaheaastanejarjekordenimmuududraamatudmillesseisnebravijareneburklandifenomen?id=76046833 (accessed December 14, 2016).

T12 = Järvik, Elise. 2018. Hiina meditsiin aitab rajale tagasi. - Kodutohter 2: 52-54. 


\section{REFERENCES}

ACIMH $=$ Academic Consortium for Integrative Medicine and Health. https://imconsortium.org/ about/introduction/ (accessed January 11, 2020).

Anderson, Joan and Sheryl Reimer Kirkham. 1999. Discourses on Health: A Critical Perspective. A Cross-Cultural Dialogue on Health Care Ethics, edited by Harold Coward and Pinit Ratanakul. Waterloo: Wilfrid Laurier University Press, 47-67.

Baer, Hans A. 2008. The Emergence of Integrative Medicine in Australia. The Growing Interest of Biomedicine and Nursing in Complementary Medicine in a Southern Developed Society. - Medical Anthropology Quarterly 22 (1): 52-66. DOI: https://doi.org/10.1111/j.15481387.2008.00003.x.

Barcan, Ruth. 2011. Complementary and Alternative Medicine. Bodies, Therapies, Senses. Oxford; New York, NY: Berg.

Benelli, Eva. 2003. The Role of the Media in Steering Public Opinion on Healthcare Issues. -Health Policy 63 (2): 179-186. DOI: https://doi.org/10.1016/S0168-8510(02)00064-7.

Bligh, Michelle and Jill Robinson. 2010. Was Gandhi "Charismatic"? Exploring the Rhetorical Leadership of Mahatma Gandhi. - The Leadership Quarterly 21: 844-855. DOI: https://doi. org/10.1016/j.leaqua.2010.07.011.

Boss, George P. 1976. Essential Attributes of the Concept of Charisma. - Southern Speech Communication Journal 41 (3): 300-313. DOI: https://doi.org/10.1080/10417947609372316.

Briggs, Charles and Daniel Hallin. 2016. Making Health Public: How News Coverage Is Remaking Media, Medicine, and Contemporary Life. London; New York, NY: Routledge. DOI: https://doi. org/10.4324/9781315658049.

Bryman, Alan. 1992. Charisma, and Leadership in Organizations. London: Sage.

Bürkland, Rene. 2014. Tervise alkeemia. Hiina meditsiiniline lähenemine tervisele ja haigustele. Tallinn: Pilgrim.

Bürkland, Rene. 2016. Tark tee terviseni. Hiina toitumisteraapia tervise tugevdamiseks ja haigustest paranemiseks. Tallinn: Pilgrim.

Caldwell, Elizabeth Frances. 2017. Quackademia? Mass-Media Delegitimation of Homeopathy Education. - Science as Culture 26 (3): 380-407. DOI: https://doi.org/10.1080/09505431.2017.1 316253.

Cant, Sarah and Ursula Sharma. 1999. A New Medical Pluralism? Alternative Medicine, Doctors, Patients and the State. London; New York, NY: Routledge.

Coulter, Ian. 2004. Integration and Paradigm Clash: The Practical Difficulties of Integrative Medicine. - The Mainstreaming of Complementary and Alternative Medicine, edited by Philip Tovey, Gary Easthope and Jon Adams. New York, NY; London: Routledge, 103-122. DOI: https://doi. org/10.4324/9780203987902-10.

Crant, J. Michael and Thomas S. Bateman. 2000. Charismatic Leadership Viewed from above: The Impact of Proactive Personality. - Journal of Organizational Behaviour 21: 63-75. DOI: https:// doi.org/10.1002/(SICI)1099-1379(200002)21:1<63::AID-JOB8>3.0.CO;2-J.

Crawford, Robert. 1980. Healthism and the Medicalization of Everyday Life. - International Journal of Health Services 10 (3): 365-388. DOI: https://doi.org/10.2190/3H2H-3XJN-3KAY-G9NY.

Denny, Keith 1999. Evidence-Based Medicine and Medical Authority. - Journal of Medical Humanities 20 (4): 247-263. DOI: https://doi.org/10.1023/A:1022924404779.

EAYS = The Estonian Medical Students' Association. https://eays.ee/ (accessed January 11, 2020).

Ernst, Edzard. 2011. How Much of CAM Is Based on Research Evidence? - Evidence-Based Complementary and Alternative Medicine. DOI: https://doi.org/10.1093/ecam/nep044. 
Ernst, Edzard and Thomas Weihmayr. 2000. UK and German Media Differ over Complementary Medicine. - British Medical Journal Clinical Research 321: 707.

EUROCAM = What Is CAM. - EUROCAM. https://cam-europe.eu/foundation-of-cam-umbrellaorganisations/what-is-complementary-and-alternative-medicine (accessed January 11, 2020).

Fairclough, Norman. 2003. Analysing Discourse. Textual Analysis for Social Research. London; New York, NY: Routledge. DOI: https://doi.org/10.4324/9780203697078.

Fries, Christopher J. 2009. Bourdieu's Reflexive Sociology as a Basis for Mixed Methods Research: An Application to Complementary and Alternative Medicine. - Journal of Mixed Methods Research 3(4): 326-348. DOI: https://doi.org/10.1177/1558689809336660.

Hammer, Olav. 2001. Claiming Knowledge: Strategies of Epistemology from Theosophy to the New Age. Leiden; Boston, MA; Köln: Brill.

Harnett, Susan and Jane Morgan-Daniel. 2018. Health Literacy Considerations for Users of Complementary and Alternative Medicine. - Journal of Consumer Health on the Internet 22 (1): 63-71. DOI: https://doi.org/10.1080/15398285.2018.1415593.

den Hartog, Deanne N. and Robert M. Verburg. 1997. Charisma and Rhetoric: Communicative Techniques of International Business Leaders. - Leadership Quarterly 8 (4): 355-391. DOI: https://doi.org/10.1016/S1048-9843(97)90020-5.

Health Board. 2019a. Algab terviseameti kampaania “Tervis pole naljaasi”. - Terviseamet. https:// www.terviseamet.ee/et/uudised/algab-terviseameti-kampaania-tervis-pole-naljaasi (accessed April 27, 2019).

Health Board. 2019b. Ebaravi. - Terviseamet. https://www.terviseamet.ee/et/ebaravi (accessed April 27, 2019).

Hjarvard, Stig. 2008. The Mediatization of Society. - Nordicom Review 29 (2): 105-134. DOI: https:// doi.org/10.1515/nor-2017-0181.

Hoenders, H. J. Rogier; Martin T. Appelo, Erik van den Brink, Bregje M. A. Hartogs and Joop Tvm de Jong. 2011. The Dutch Complementary and Alternative Medicine (CAM) Protocol: To Ensure the Safe and Effective Use of Complementary and Alternative Medicine within Dutch Mental Health Care. - The Journal of Alternative and Compementary Medicine 17 (12): 1197-1201. DOI: https://doi.org/10.1089/acm.2010.0762.

Hollenberg, Daniel and Linda Muzzin. 2010. Epistemological Challenges to Integrative Medicine: An Anticolonial Perspective on the Combination of Complementary/Alternative Medicine with Biomedicine. - Health Sociology Review 19 (1): 34-56. DOI: https://doi.org/10.5172/ hesr.2010.19.1.034.

House, Robert J.; William D. Spangler and James Woycke. 1991. Personality and Charisma in the U.S. Presidency: A Psychological Theory of Leader Effectiveness. - Administrative Science Quarterly 36: 364-396. DOI: https://doi.org/10.2307/2393201.

Hughes, Kahryn. 2004. Health as Individual Responsibility: Possibilities and Personal Struggle. - The Mainstreaming of Complementary and Alternative Medicine, edited by Philip Tovey, Gary Easthope and Jon Adams. New York, NY; London: Routledge, 25-46.

Ilves, Liis. 2017. Haigekassa Hiina meditsiini praktiseerimisest: arst peab patsienti ravima arstiteaduse reeglite järgi. - Med24. https://www.med24.ee/uudised/haigekassa-hiina-meditsiini-praktiseerimisest-arst-peab-patsienti-ravima-arstiteaduse\#com\%E2\%80\%A6 (accessed January 11, 2020).

Jensen, Bjarne Bruun. 1997. A Case of Two Paradigms within Health Education. - Health Education Research 12 (4): 419-428. DOI: https://doi.org/10.1093/her/12.4.419.

Johnston, Jay. 2010. Subtle Anatomy: The Bio-metaphysics of Alternative Therapies. - International Studies in Religion and Society 11. Medicine, Religion, and the Body, edited by Elizabeth Burns 
Coleman and Kevin White. Leiden; Boston, MA: Brill, 69-78. DOI: https://doi.org/10.1163/ ej.9789004179707.i-300.28.

Johnston, Jay and Ruth Barcan. 2006. Subtle Transformations: Imagining the Body in Alternative Health Practices. - International Journal of Cultural Studies 9 (1): 25-44. DOI: https://doi. org/10.1177/1367877906061163.

Kelly, Bridget; Robert Hornik, Anca Romantan, J. Sanford Schwartz, Katrina Armstrong, Angela DeMichele, Martin Fishbein, Stacy Gray, Shawnika Hull, Annice Kim, Rebekah Nagler, Jeff Niederdeppe, A. Susana Ramírez, Aaron Smith-McLallen and Norman Wong. 2010. Cancer Information Scanning and Seeking in the General Population. - Journal of Health Communication 15 (7): 734-753. DOI: https://doi.org/10.1080/10810730.2010.514029.

Kelner, Merrijoy; Beverly Wellman, Heather Boon and Sandy Welsh. 2004. Responses of Established Healthcare to the Professionalization of Complementary and Alternative Medicine in Ontario. - Social Science and Medicine (59): 915-930. DOI: https://doi.org/10.1016/j.socscimed.2003.12.017.

Keshet, Yael. 2009. The Untenable Boundaries of Biomedical Knowledge: Epistemologies and Rhetoric Strategies in the Debate over Evaluating Complementary and Alternative Medicine. - Health: An Interdisciplinary Journal for the Social Study of Health, Illness and Medicine 13 (2): 131-155. DOI: https://doi.org/10.1177/1363459308099681.

Keshet, Yael. 2013. Dual Embedded Agency: Physicians Implement Integrative Medicine in Health-care Organizations. - Health: An Interdisciplinary Journal for the Social Study of Health, Illness and Medicine 17 (6): 605-621. DOI: https://doi.org/10.1177/1363459312472084.

Koppel, Katre. 2018. "My Dream Is to Bring Together Chinese and Western Medicine": Why Chinese Medicine Is Making Its Way into Estonian Healthcare. - Curare. Journal of Medical Anthropology 41 (1-2): 63-78.

Koppel, Katre and Marko Uibu. Forthcoming. From Alternative Healing to Holistic Well-Being: Media Representation Analysis of Three Significant Estonian Medical Doctors.

Korp, Peter. 2010. Problems of the Healthy Lifestyle Discourse. - Sociology Compass 4 (9): 800-810. DOI: https://doi.org/10.1111/j.1751-9020.2010.00313.x.

Krotz, Friedrich. 2017. Explaining the Mediatisation Approach. - Javnost - The Public 24 (2): 103118. DOI: https://doi.org/10.1080/13183222.2017.1298556.

Kuckartz, Udo. 2014. Qualitative Text Analysis. Los Angeles, CA; London; New Delhi; Singapore; Washington, DC: Sage.

van Leeuwen, Theo. 2007. Legitimation in Discourse and Communication. - Discourse and Communication 1 (1): 91-112. DOI: https://doi.org/10.1177/1750481307071986.

van Leeuwen, Theo. 2008. Discourse and Practice: New Tools for Critical Discourse Analysis. New York, NY: Oxford University Press.

Leung, Shirley; Kylie Chan and Lisa Song. 2006. Publishing Trends in Chinese Medicine and Related Subjects Documented in WorldCat. - Health Information and Libraries Journal 23 (1): 13-22. DOI: https://doi.org/10.1111/j.1471-1842.2006.00636.x.

Lewis, Monique. 2019. De-legitimising Complementary Medicine: Framings of the Friends of Science in Medicine-CAM Debate in Australian Media Reports. - Sociology of Health and Illness 41: 831-851. DOI: https://doi.org/10.1111/1467-9566.12865.

Lubi, Kadi; Triin Vihalemm and Pille Taba. 2016. Patients' Interpretation of CAM-Related Information: Manoeuvring Between Patient and Consumer Positionings. - The Power of the Media in Health Communication, edited by Valentina Marinescu and Bianca Mitu. Oxon: Routledge, 73-90. DOI: https://doi.org/10.4324/9781315554068-6.

Lundby, Knut. 2014. Mediatization of Communication. Handbooks of Communication Science 21. Berlin; Boston, MA: De Gruyter. DOI: https://doi.org/10.1515/9783110272215. 
Lupton, Deborah. 1995. The Imperative of Health: Public Health and the Regulated Body. London: Sage Publications.

Maarits, Merit. 2017. Amet: "tervendajate" tegevust ei saa piirata, sest Eestis on demokraatia. - ERR. https://www.err.ee/615145/amet-tervendajate-tegevust-ei-saa-piirata-sest-eestis-ondemokraatia (accessed February 23, 2020).

Miskelly, Philippa Ann. 2006. Healing Pluralism and Responsibility: An Anthropological Study of Patient and Practitioner Beliefs. Doctoral dissertation. University of Waikato, Hamilton, New Zealand. https://researchcommons.waikato.ac.nz/bitstream/handle/10289/2560/thesis. pdf? sequence $=1 \&$ isAllowed $=y$ (accessed February 10, 2020).

Moral-Muñoz, Jose A.; Manuel J. Cobo, E. Peis, Manuel Arroyo-Morales and Enrique HerreraViedma. 2014. Analyzing the Research in Integrative and Complementary Medicine by Means of Science Mapping. - Complementary Therapies in Medicine 22 (2): 409-418. DOI: https://doi. org/10.1016/j.ctim.2014.02.003.

Nael, Merili. 2019. Uuenev rahvatervise seadus tõhustab muu hulgas ebaravivastast võitlust. - Eesti Rahvusringhä̈ling. https://www.err.ee/994347/uuenev-rahvatervise-seadus-tohustabmuu-hulgas-ebaravivastast-voitlust (accessed November 13, 2019).

Nettleton, Sarah. 2013. The Sociology of Health and Illness. 3rd edn. Cambridge: Polity Press.

Ng, Jeremy Y.; Heather S. Boon, Alison K. Thompson and Cynthia R. Whitehead. 2016. Making Sense of "Alternative", "Complementary", "Unconventional" and "Integrative" Medicine: Exploring the Terms and Meanings through a Textual Analysis. - BMC Complementary and Alternative Medicine 16 (134). DOI: 10.1186/s12906-016-1111-3.

Nordenfelt, Lennart. 2007. The Concepts of Health and Illness Revisited. - Medicine, Health Care and Philosophy 10: 5-10. DOI: https://doi.org/10.1007/s11019-006-9017-3.

Rojo, Luisa Martin and Teun A. van Dijk. 1997. “There Was a Problem, and It Was Solved!": Legitimating the Expulsion of 'Illegal' Migrants in Spanish Parliamentary Discourse. - Discourse and Society 8 (4): 523-566. DOI: https://doi.org/10.1177/0957926597008004005.

Schmidt, Josef M. 2009. Is Homeopathy a Science? - Continuity and Clash of Concepts of Science within Holistic Medicine. - Journal of Medical Humanities 30: 83-97. DOI: https://doi. org/10.1007/s10912-009-9080-x.

Seale, Clive. 2003. Health and Media: An Overview. - Sociology of Health and Illness 25 (6): 513-531. DOI: https://doi.org/10.1111/1467-9566.t01-1-00356.

Sutcliffe, Steven J. and Ingvild Saelid Gilhus. 2013. New Age Spirituality. Rethinking Religion. Durham: Acumen. DOI: https://doi.org/10.4324/9781315729541.

Takala, Tuomo; Sanja Tanttu, Anna-Maija Lämsä and Aila Virtanen. 2013. Discourses of Charisma: Barack Obama's First 6 Months as the President of the USA. - Journal of Business Ethics 115: 149-166. DOI: https://doi.org/10.1007/s10551-012-1389-0.

Tikk, Arvo. 2005. Arstid ja alternatiivmeditsiin. - Eesti Arst 84 (4): 294-296.

Titscher, Stefan; Michael Meyer, Ruth Wodak and Eva Vetter. 2000. Methods of Text and Discourse Analysis. London; Thousand Oaks, CA; New Delhi: Sage Publications.

Uibu, Marko. 2016a. Reemerging Religiosity: The Mainstreaming of New Spirituality in Estonia. Journal of Baltic Studies 47 (2): 257-274. DOI: https://doi.org/10.1080/01629778.2015.1113432.

Uibu, Marko. 2016b. Hidden Religiosity in One of the World's Least Religious Countries: Estonian Doctor Luule Viilma and Her Spiritual Teachings. - Implicit Religion 19 (2): 267-282. DOI: https://doi.org/10.1558/imre.v19i2.29777.

Uibu, Marko and Katre Koppel. Forthcoming. Beyond Medical Pluralism: Communicative Positioning of Biomedicine and Alternative Medicines in Estonia.

Vaara, Eero. 2014. Struggles over Legitimacy in the Eurozone Crisis: Discursive Legitimation Strategies and Their Ideological Underpinnings. - Discourse and Society 25 (4): 500-518. DOI: https://doi.org/10.1177/0957926514536962. 
Võsumets, Marian. 2015. Arstide liit toetab lastearste MMSi vastases võitluses. - Postimees Tervis. https://tervis.postimees.ee/3340327/arstide-liit-toetab-lastearste-mmsi-vastases-voitluses (accessed January 11, 2020).

Weber, Max. 1978 [1947]. Economy and Society. An Outline of Interpretive Sociology, edited by Guenther Roth and Claus Wittich. Berkeley, CA; Los Angeles, CA; London: University of California Press.

Weeks, Laura; Marja Verhoef and Catherine Scott. 2007. Presenting the Alternative: Cancer and Complementary and Alternative Medicine in the Canadian Print Media. - Support Care Cancer 15 (8): 931-938. DOI: https://doi.org/10.1007/s00520-007-0290-3.

Weeks, Laura and Tina Strudsholm. 2008. A Scoping Review of Research on Complementary and Alternative Medicine (CAM) and the Mass Media: Looking Back, Moving Forward. - BMC Complementary and Alternative Medicine 8 (43). DOI: https://doi.org/10.1186/1472-6882-8-43.

Wiese, Marlene and Candice Oster. 2010. 'Becoming accepted': The Complementary and Alternative Medicine Practitioners' Response to the Uptake and Practice of Traditional Medicine Therapies by the Mainstream Health. - Health: An Interdisciplinary Journal for the Social Study of Health, Illness and Medicine 14 (4): 415-433. DOI: https://doi.org/10.1177/1363459309359718.

Wiese, Marlene; Candice Oster and Jan Pincombe. 2010. Understanding the Emerging Relationship between Complementary Medicine and Mainstream Health Care: A Review of the Literature. - Health: An Interdisciplinary Journal for the Social Study of Health, Illness and Medicine 14 (3): 326-342. DOI: https://doi.org/10.1177/1363459309358594. 